\title{
"ABCDEF Checklist" based on 3D radiological images for preoperative planning of endoscopic sinus surgery*
}

\author{
J.M. Maza-Solano', J. González-García', R. Moreno-Luna', J. Ambrosiani- \\ Fernández², E. Domínguez-Durán', S. Sánchez-Gómez'
}

'Rhinology and Anterior Skull Base Department Section, University Hospital Virgen Macarena, Seville, Spain

Department of Anatomy and Human Embryology, University of Seville, Seville, Spain
Rhinology Online, Vol 1: 133 - 142, 2018

http://doi.org/10.4193/RHINOL/18.054

*Received for publication:

August 21, 2018

Accepted: October 4, 2018

Published: October 6, 2018

\begin{abstract}
Background: Endoscopic sinus surgery (ESS) is performed on endonasal landmarks that have great anatomical variability, therefore a detailed preoperative study of these structures is necessary.
\end{abstract}

Objective: To develop a checklist for the systematic identification of the paranasal sinuses and the skull base, based on 3D images that guide the planning and implementation of ESS to minimize complications and improve surgical outcomes.

Methods: This study evaluates the usefulness of the "ABCDEF Checklist", in a randomized study involving 30 otolaryngologists with more than 2 years of practical experience in ESS evaluating preoperative radiological examination and subsequent surgical performance in the sinus of 30 cadavers.

Results: Differences between groups in identifying the essential anatomical references were significant in 9 of the 11 essential anatomical references for the Checklist Group Surgical procedures and surgical mistakes were performed systematically less often in the Checklist group but the differences did not reach significance after Bonferroni correction.

Conclusions: The use of "ABCDEF Checklist" prior to ESS facilitates the identification of the essential anatomical references for the preoperative and systematized planning of the surgical procedures. However, in this small sample of 15 particiants per group the differences found in the performace of the surgical procedures did not reach significance.

Key words: paranasal sinuses, nasal surgical procedures, chronic rhinosinusitis, education radiology, sinus surgery, pre-operative checklist, endoscopic sinus surgery

\section{Introduction}

Endoscopic sinus surgery (ESS) is one of the surgical procedures most frequently performed in otolaryngology ${ }^{(1)}$. The appropriateness criteria of ESS (except oncological pathology) focus on defining three clinical factors: 1 ) the need for objective evidence of chronic rhinosinusitis (CRS) using computed tomography (CT) imaging, 2) the degree of patient-reported disease burden using the 22-item SinoNasal Outcome Test (SNOT-22), and 3) the medical therapy used prior to offering ESS. But the decision to perform ESS should be made after an informed patient makes a preference-sensitive decision to proceed with surgery ${ }^{(2,3)}$. Alt- hough ESS is a surgery with high success rates, it is a procedure with potentially serious complications such as damage to the orbit, severe epistaxis or cerebrospinal fluid leak (CSF leak), due to the proximity of the paranasal sinuses to other key structures $^{(4-6)}$. Knowledge and study of anatomical references through images and videos, as well as training programs with cadaver dissection $^{(7)}$, do not always prevent complications or improve outcomes for neither experienced surgeons nor otolaryngology residents ${ }^{(8,9)}$.

There is great diversity in sinonasal anatomy and sinonasal landmarks ${ }^{(10,11)}$, so it is necessary to have a detailed study of 
radiological images in order to assess each patient individually ${ }^{(12)}$. Checklists based on radiological images have been used to improve ESS and reduce avoidable surgical mistakes, through the systematization of the necessary steps during surgery ${ }^{(13-15)}$. Technological development of radiological and imaging technologies has been complemented by the widespread use of computer software programs that allow surgeons to see and manipulate radiological images from DICOM files without relying on hospital image systems. The main contribution of these programs lies in that they offer three-dimensional recreations (3D) of anatomical structures and therefore it is possible to visualize these structures simultaneously in the three planes of space.

The major contribution of this study is the development of a checklist of the paranasal sinuses and the anterior skull base, based on 3D images that guide the planning and implementation of ESS to minimize complications and improve surgical outcomes.

\section{Materials and Methods}

Design of the ABCDEF mnemonic rule for anatomical references.

A checklist was developed for the systematic identification of the sinonasal and skull base relevant anatomical structures, using the abbreviation $A B C D E F$, with the aim of demonstrating its usefulness in the 3D planning of ESS, based on an improvement in the identification of endonasal landmarks when performing surgical procedures, and thus minimizing complications. Through this mnemonic rule, each letter corresponds to the initial of a relevant anatomical landmark or an endonasal area (Figure 1). In brief, the checklist is designed as follows: Letter "A", stands for Alignment of the nasal septum, Agger Nasi, the apophysis of the uncinate process and 3 arteries (anterior and posterior ethmoidal artery, and the sphenopalatine artery) were analyzed. Letter "B" refers to the ethmoidal Bulla. The following region refers to the Middle Turbinate, but in order to comply with the mnemonic rule "ABCDEF", the letter " $T$ " (turbinate in English) was transformed into " $\mathrm{C}$ " (Concha Nasi in the anatomical terminology taken from "Latin"). Letter "D" represents the Dimensions corresponding to the Classification of Keros, the narrowest area of the ethmoidal infundibulum and the symmetry between the right and left lamina papyracea. Finally, letter "E" corresponds to the Ethmoid and the Sphenoid, while letter "F" refers to the Frontal sinus.

\section{"Step by step" for the 3D recreation of the "ABCDEF Check-} list".

Location, shape, dimensions and relationships of each anatomical landmark of the "ABCDEF Checklist" were determined by the free software Horos ${ }^{\oplus}$. From the simultaneous visualization in a single screen of the CT using triplane images, $\operatorname{Horos}^{\oplus}$ was used to synchronize positioning, thus obtaining a 3D recreation from the two-dimensional static images of the original DICOM file. Below, the procedure applied to the Agger Nasi cell (AN) ${ }^{(16)}$ is exemplified in Figure 2. The remaining anatomical references included in the "ABCDEF Checklist" are evaluated with the same methodology, with the variation of the main execution plane during the procedure (axial, coronal or sagittal) (Table 1). AN is the most anterior part of the ethmoid, (Figure 2A) and may be seen on intranasal examination as a small prominence on the lateral nasal wall just anterior to the attachment of the middle turbinate. The proposed steps for pre-surgical 3D planning of the AN with Horos $^{\circledR}$ are: 1) Study selection: with the largest number of images to reduce the pixelation of 3D reconstruction, 2) 3D viewer "Tridimensional Multiplanar Reconstruction" (3DMPR): mode allows direct reconstruction in 3D using volumes, surfaces and endoscopic images. However, the choice of 3DMPR mode as a previous step to three-dimensional reconstructions is a highly recommended option to make a simultaneous navigation in the three planes of space, since it allows selecting those regions of interest (ROIs) that are going to be reconstructed. (Figure 2B), 3) The preoperative planning with the 3DMPR to AN begins in the coronal views, with the anteroposterior sliding of the DICOM images that will appear in close connection to the frontal beak (Figure 2C), 4) In the sagittal, axial and coronal view, the relationship of other structures with respect to the position of AN can be determined (Figure 2D). 5) Finally, the 3D volumetric interpretation of each of the anatomical regions studied is performed through the 3D Volume Rendering function (Figure $2 \mathrm{E})$. 6) The final 3D sequence is achieved (Figure 2F).

\section{Design of the study}

The study analyzed the potential of this "ABCDEF Checklist" in the correct identification of essential anatomical references ${ }^{(17)}$ in ESS, and in the evaluation of the adequate approach in the different surgical procedures carried out in 60 nasal cavities of frozen cadaver ( $n=60,30$ left and 30 right nasal cavities), by 30 otolaryngologist with more than 2 years of practical experience in ESS, distributed in two groups. The surgeons were randomly assigned by drawing cards from a shuffled stack including 15 cards with number " 1 " (Use the CHECKLIST) and the other 15 with the number " 2 " (DO NOT use the CHECKLIST).

The Checklist Group carried out the pre-surgical planning before each proposed surgical procedure following the "ABCDEF checklist" step by, and recreating the structures three-dimensionally with Horos ${ }^{\circledast}$. Parallelly, surgeons in Control Group carried out pre-surgical planning based on their own experience, without the support of the "ABCDEF checklist", although all of the members of this group also had the Horos ${ }^{\circledR}$ program installed in their workstations to evaluate scans prior to dissection. All surgeons participating in the dissection accepted the randomization process by which they could belong to either the group can go. 


\begin{tabular}{|c|c|c|}
\hline \multicolumn{3}{|l|}{ Alignment of the Nasal Septum } \\
\hline Deyiation side & ص Right & Bilateral \\
\hline & 口High & Both \\
\hline Location of the deviation & a Posterior & Both \\
\hline Agger nasi & Right & Left \\
\hline Agger nasi cell & $\square$ Yes $\square$ No & $\square$ Yes $\square$ No \\
\hline Supra agger cell & $\square$ Yes $\sqcup$ No & $\square$ Yes $\sqcup$ No \\
\hline Supra agger frontal cell & $\square$ Yes $\square$ No & 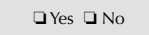 \\
\hline Apophysis of the Uncinate Process & Right & Left \\
\hline Attachment to the nasolacrimal sac and duct & $\sqcup$ Yes $\sqcup$ No & $\square$ Yes $\sqcup$ No \\
\hline Attachment to the agger nasi & $\square$ Yes $\square$ No & $\square$ Yes $\sqcup$ No \\
\hline Attachment to the the middle turbinate & $\sqsupset$ Yes $\square$ No & $\square$ Yes $\square$ No \\
\hline Attachment to the lamina papyracea & $\square$ Yes $\square$ No & $\square$ Yes $\square$ No \\
\hline Attachment to the skull base & $\square$ Yes $\sqcup$ No & $\square$ Yes $\square$ No \\
\hline Permeability of the ostiomeatal complex & ปYes $\sqcup$ No & ปYes $\square$ No \\
\hline Anterior ethmoidal Artery & Right & Left \\
\hline Bony lamella dehiscent & ปYes $\sqcup$ No & $\square$ Yes $\square$ No \\
\hline Location at the suprabullar recess & $\square$ Yes $\square$ No & $\square$ Yes $\square$ No \\
\hline Distance to the frontal beak & _ millimeters & __ millimeters \\
\hline Distance to the ground of the ethmoidal bulla & __ millimeters & $\ldots$ millimeters \\
\hline Posterior ethmoidal Artery & Right & Left \\
\hline Bony lamella dehiscent & $\square$ Yes $\sqcup$ No & $\square$ Yes $\square$ No \\
\hline Distance from anterior to posterior ethmoidal artery & __ millimeters & $\ldots \ldots$ millimeters \\
\hline Distance from posterior ethmoidal artery to optic canal & __ millimeters & $\ldots$ millimeters \\
\hline Artery sphenopalatine & Right & Left \\
\hline $\begin{array}{l}\text { Conection between the sphenopalatine foramen and } \\
\text { pterygomaxillary fissure }\end{array}$ & ¿Yes $\sqcup$ No & $\square$ Yes $\square$ No \\
\hline Bulla & Right & Left \\
\hline Location of the ethmoidal bulla & $\square$ Yes $\sqcup$ No & $\square$ Yes $\square$ No \\
\hline $\begin{array}{l}\text { Does the medial wall of the orbit correspond to the } \\
\text { thmoidal bulla lateral wall? }\end{array}$ & $\square$ Yes $\square$ No & $\square$ Yes $\square$ No \\
\hline Location and number of supra bulla cells* & $\longrightarrow$ & \\
\hline Location and number of supra bulla frontal cells* & & \\
\hline Location and number of retro bulla cells* & (n) & - \\
\hline Location and number of supraorbital ethmoid cell* & - & 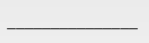 \\
\hline Retrobullar recess & $\square$ Yes $\square$ No & $\square$ Yes $\triangle$ No \\
\hline Suprabullar recess & $\square$ Yes $\square$ No & $\square$ Yes $\square$ No \\
\hline Supraorbital recess & コYes $\sqcup$ No & $\square$ Yes $\square$ No \\
\hline Anterior and posterior ethmoidal artery (review) & ם & $\square$ \\
\hline${ }^{*}$ Different frontoethmoidal cells variants & & \\
\hline "Concha nasi inferior" (Inferior turbinate) & Right & Left \\
\hline Aypertrofic inferior turbinate & $\square$ Yes $\sqcup$ No & $\sqsupset$ Yes $\square$ No \\
\hline "Concha nasi superior" (Superior turbinate & Right & Left \\
\hline Relation with the spheno-ethmoidal recess & $\square$ Yes $\square$ No & $\sqcup$ Yes $\sqcup$ No \\
\hline
\end{tabular}

\begin{tabular}{|c|c|c|}
\hline "Concha nasi media" (Middle turbinate) & Right & Left \\
\hline Concha bullosa & $\square$ Yes $\square$ No & $\sqsupset$ Yes $\sqcup$ No \\
\hline Anterior attachment to the agger nasi (axilla) & $\square$ Yes $\square$ No & $\square$ Yes $\sqcup$ No \\
\hline Posterior attachment to the lamina papyracea (basal lamella) & 口Yes 」No & 口Yes 」No \\
\hline Vertical attachment to the skull base & $\square$ Yes $\square$ No & $\square$ Yes $\sqcup$ No \\
\hline Interlamellar cell (lamella bulla) & $\square$ Yes $\square$ No & 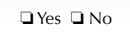 \\
\hline Dimensions & Right & Left \\
\hline Keros classification & 3 & 3 \\
\hline Distance from the frontal beak to the olfactory fossa & _ millimeters & $\ldots$ millimeters \\
\hline Narrower area of the ethmoidal infundibulum & _ millimeters ${ }^{2}$ & $\ldots$ millimeters 2 \\
\hline Symmetry in the coronal plane of the lamina papyracea & 凹Yes $\sqcup$ No & コYes 口 No \\
\hline Symmetry in the axial plane of the lamina papyracea & $\square$ Yes $\square$ No & ปYes 口 № \\
\hline Ethmoidal complex & Right & Left \\
\hline Agger nasi (review) & ם & د \\
\hline Uncinate process (review) & د & د \\
\hline Anterior and posterior ethmoidal artery (review) & د & 口 \\
\hline Bulla (review) & ב & ב \\
\hline Keros classification (review) & a & $\square$ \\
\hline Middle turbinate (review) & ב & a \\
\hline Ethmoidal infundibulum continues with the frontal recess? & $\square$ Yes $\square$ No & ¿Yes 口 No \\
\hline Ethmoidal infundibulum continues with the terminal recess? & $\square$ Yes $\square$ No & 马Yes コ No \\
\hline Ethmoidal roof & ปYes 」No & ปYes घ No \\
\hline \multicolumn{3}{|l|}{ Location and number of ethmoidal posterior cells } \\
\hline Spheno-ethmoidal cell (Onodi cell) & $\square$ Yes $\square$ No & $\square$ Yes $\square$ No \\
\hline
\end{tabular}

\section{SphEnoid sinus (pneumatization)}

\begin{tabular}{|c|c|c|c|}
\hline Sagittal plane & ב Pre-sellar & Sellar & Conchal \\
\hline Coronal plane (right sphenoid sinus) & a Previdian & Intercanal & ב Postrotundum \\
\hline Coronal plane (left sphenoid sinus) & ב Previdian & Intercanal & Postrotundum \\
\hline
\end{tabular}

\begin{tabular}{|c|c|c|}
\hline SphEnoid sinus & Right & Left \\
\hline Vertical walls & בYes & $\square$ Yes $\square$ No \\
\hline Horizontal walls & 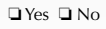 & $\square$ Yes $\square$ No \\
\hline Spheno-ethmoidal cell (review) & ם & ב \\
\hline Optico-carotid recess & $\square$ Yes $\square$ No & $\square$ Yes $\square N_{0}$ \\
\hline
\end{tabular}

\begin{tabular}{|c|c|c|}
\hline Frontal sinus & Right & Left \\
\hline Agger nasi (review) & ם & ם \\
\hline Uncinate process (review) & a & ם \\
\hline Bulla (review) & a & ם \\
\hline Middle turbinate (review) & ם & ם \\
\hline Infundibulum, frontal recess and terminal recess (review) & ם & ם \\
\hline Anterior and posterior ethmoidal artery (review) & a & ם \\
\hline Keros classification (review) & ם & ם \\
\hline Distance from the frontal beak to the olfactory fossa (review) & ב & ם \\
\hline
\end{tabular}

Figure 1. "ABCDEF checklist" for preoperative planning of ESS. 

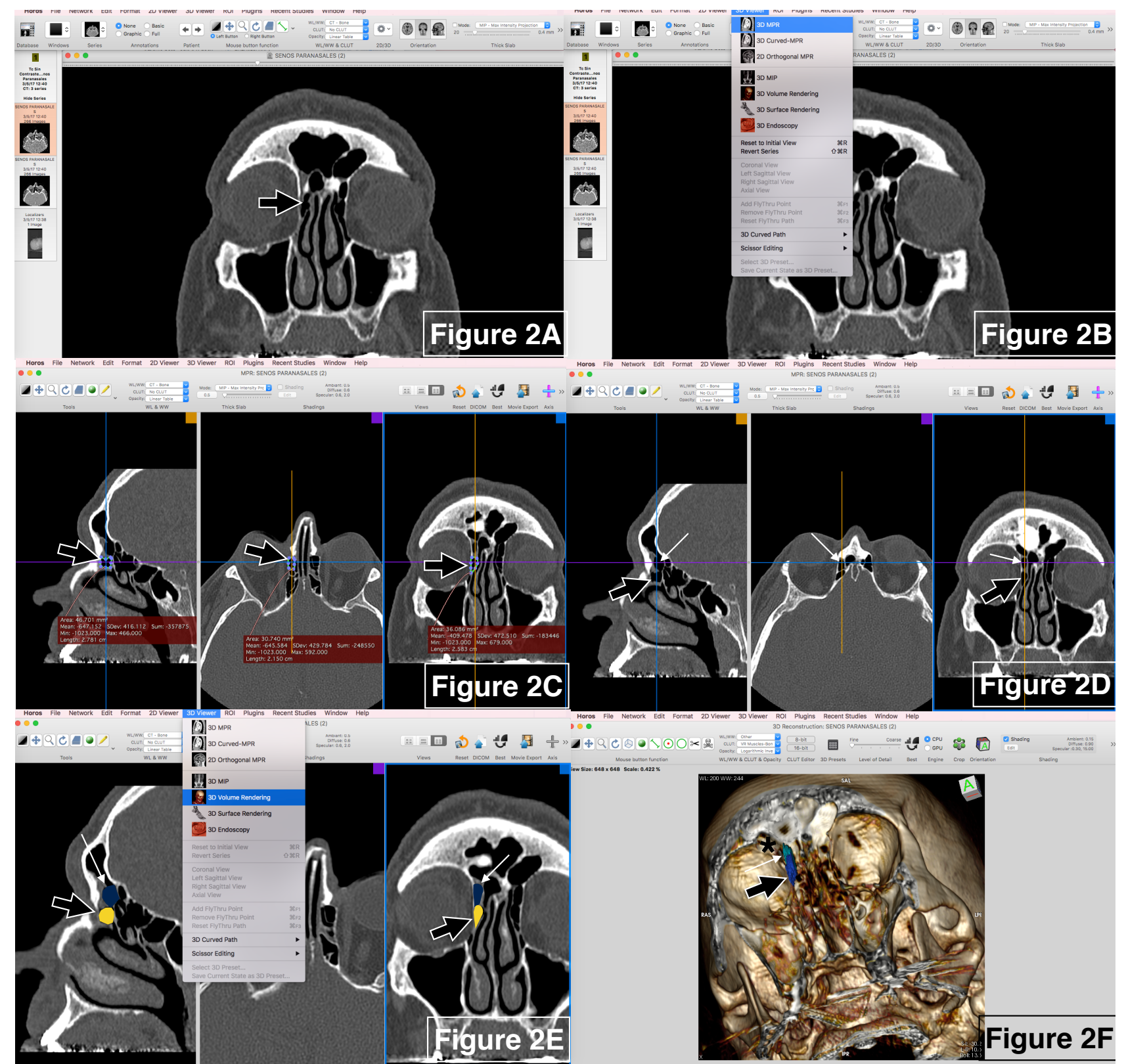

Figure 2. Proposed steps for pre-surgical 3D planning of the AN with Horos ${ }^{\oplus}$. A) Study selection: Select the largest number DICOM images. B) 3DMPR as a preliminary step to three-dimensional reconstructions using volumetric images and regions of interest (ROIs). C) Location of the Agger Nasi in the coronal views. D) Relationship of Agger Nasi with other structures in the 3 planes of space. E) 3D volumetric interpretation of the anatomical regions studied is performed through the 3D Volume Rendering function. F) Final 3D sequence.

\section{Statistical analysis}

Three types of outcomes were analyzed between the two study groups with an agreement between evaluators by Cohen's Kappa coefficient was 0.85 .

First, the difficulty of identifying the 11 essential anatomical references for the correct and safe management of ESS was assessed (Table 1.1). The difficulty was measured by a self-administered numerical scale with values from 0 to 10 ( 0 meant the least possible difficulty during the dissection and 10 the greatest difficulty). The mean difficulty to identify each reference found by each study groups was compared using the t-Student when data weret normally distributed, and the Mann-Whitney $U$ test when they were not. Normality was tested through the ShapiroWilk test. After Bonferroni correction for multitesting a $p$ value $<0.005$ was considered to be significant.

Second, a post-dissection CT control was performed to evaluate the 7 surgical procedures performed(18). Each post-dissection CT was anonymized to ensure blinding by the evaluators. The assessors didn't know whether the identification of essential anatomical references, the surgical procedures and the mistakes 
Table 1. Anatomical references, proposed surgical procedures and complications detected during ESS.

1. Essential anatomical references and radiological planes for pre-surgical planning.

1. Alignment of the nasal septum and its relationship with the middle meatus (Coronal $=$ Axial $>$ Sagittal).

2. Identification and dissection of the agger nasi (Coronal $>$ Sagittal $>$ Axial).

3. Identification and dissection of the uncinate process. Relationship between the uncinate process and the maxillary sinus (Coronal = Axial > Sagittal).

4. Identification of the anterior ethmoidal artery (Coronal $>$ Sagittal $>$ Axial).

5. Identification of the sphenopalatine artery (Axial $>$ Coronal $>$ Sagittal).

6. Identification and dissection of the ethmoidal bulla and the bulla complex (Coronal $=$ Sagittal $=$ Axial).

7. Identification and dissection of the frontoethmoidal cells (Coronal = Sagittal = Axial).

8. Identification and dissection of the middle turbinate and its attachments. Basal lamella of the middle turbinate (Coronal = Sagittal = Axial).

9. Identification and total dissection of ethmoids (Coronal = Sagittal $=$ Axial).

10. Identification and dissection of the sphenoid sinus. Sphenoidal approach (Coronal $=$ Sagittal $=$ Axial).

11. Identification of the frontal recess. Dissection of the frontal sinus (Coronal = Sagittal = Axial).

2. Surgical procedures

1. Complete dissection of the agger nasi cell.

2. Uncinectomy.

3. Frontal sinus dissection.

4. Ethmoidal bulla dissection.

5. Complete dissection to the different variants of frontoethmoidal cells according to the number and type that existed in the planning TC.

6. Total ethmoidectomy. Anterior and posterior ethmoidectomy to the ethmoidal roof.

7. Sphenoidotomy and sphenoidal dissection

3. Mistakes and complications.

1. Damage of the lamina papyracea or the orbit.

2. Damage of the lacrimal sac.

3. Damage of the anterior ethmoidal artery.

4. Damage of the sphenopalatine artery.

5. Damage of the cribriform plate (CSF leak).

6. Damage of the ethmoidal roof and the sphenoethmoidal recess (CSF leak).

7. Damage to the posterior wall of the sphenoid sinus (sella region).

8. Damage of the optico-carotid recess.

1.1: Anatomical references considered essential in the ESS and radiological planes ordered according to the importance for pre-surgical planning. 1.2: Surgical procedures to be performed during cadaveric dissection. 1.3: Mistakes during dissection that lead to intraoperative complications. Complications were considered for any of the 8 mistakes that could lead to surgical problems during a real surgical procedure comparable to the dissection performed on the cadaver.

were made by a surgeon in the checklist group or in the control group. The CT control was evaluated separately by two otolaryngologists with extensive experience in ESS, to reduce subjectivity during the evaluation. It was determined dichotomically (yes/no) if the objectives of the 7 surgical procedures proposed in the dissection were reached (Table 1.2), adjusting the proportion of agreement between the evaluators by Cohen's Kappa coefficient. The achievement of each surgical procedure was compared between both groups through the Chi-square test. After Bonferroni correction for multitesting a $p$ value $<0.007$ was considered to be significant.

Finally, control and quantification of the mistakes during the dissection was carried out (Table 1.3). Those that could trigger intraoperative complications in case of occurrence during an actual surgical procedure, such as damage to the lamina papyracea, arterial damage or damage to the lamina cribosa, were labelled as mistakes. The proportion of mistakes committed by each group was compared by the Mann-Whitney $U$ test. After Bonferroni correction for multitesting a $p$ value $<0.006$ was considered to be significant.

All pre and post-ESS Checklist data were de-identified, compiled, and analyzed using commercially available statistical software (SPSS v24). 
Table 2. Values of mean, median, standard deviation, range and statistical significance between the study groups (Checklist group and Control group), according to the data of normal distribution for the 11 essential anatomical references considered in the study. The difficulty measured by the numerical scale indicates that 0 points is the least possible difficulty during identification and subsequent dissection, and 10 points is the greatest possible difficulty.

\begin{tabular}{|c|c|c|c|c|c|}
\hline & $\begin{array}{l}\text { Normal } \\
\text { Distribu- } \\
\text { tion }\end{array}$ & Groups & \multicolumn{2}{|c|}{$\begin{array}{l}\text { Mean and median scores, standard de- } \\
\text { viation (SD) and range with numerical } \\
\text { scale }(0-10) \text {, depending on whether } \\
\text { there is a normal distribution }\end{array}$} & $\begin{array}{l}\text { P value, according to } \\
\text { the normal distribu- } \\
\text { tion (t-student), or not } \\
\text { (Mann-Whitney U) }\end{array}$ \\
\hline \multirow{2}{*}{$\begin{array}{l}\text { 1. Alignment of the nasal septum and its } \\
\text { relationship with the middle meatus. }\end{array}$} & \multirow{2}{*}{ Yes } & Checklist group & Mean: 1.02 points & SD: 0.64 & \multirow{2}{*}{$p=0.665$} \\
\hline & & Control group & Mean: 1,09 points & SD: 0.68 & \\
\hline \multirow{2}{*}{$\begin{array}{l}\text { 2. Identification and dissection of the agger } \\
\text { nasi. }\end{array}$} & \multirow{2}{*}{ No } & Checklist group & Median: 2,15 points & Range: 3.06 & \multirow{2}{*}{$\mathrm{p}<0.001^{*}$} \\
\hline & & Control group & Median: 8,17 points & Range: 8.16 & \\
\hline \multirow{2}{*}{$\begin{array}{l}\text { 3. Identification and dissection of the uncinate } \\
\text { process. Relationship between the uncinate } \\
\text { process and the maxillary sinus. }\end{array}$} & \multirow[t]{2}{*}{ No } & & & Range: 4.19 & \multirow[t]{2}{*}{$\mathrm{p}<0.001^{*}$} \\
\hline & & Control group & Median: 7,50 points & Range: 7.66 & \\
\hline \multirow{2}{*}{$\begin{array}{l}\text { 4. Identification of the anterior ethmoidal } \\
\text { artery. }\end{array}$} & \multirow{2}{*}{ No } & Checklist group & Median: 2,31 points & Range: 3.64 & \multirow{2}{*}{$\mathrm{p}<0.001^{*}$} \\
\hline & & Control group & Median: 5,85 points & Range: 7.11 & \\
\hline \multirow{2}{*}{ 5. Identification of the sphenopalatine artery. } & \multirow{2}{*}{ Yes } & Checklist group & Mean: 2,33 points & SD: 0.95 & \multirow{2}{*}{$\mathrm{p}<0.001^{*}$} \\
\hline & & Control group & Mean: 3,77 points & SD: 1.08 & \\
\hline \multirow{2}{*}{$\begin{array}{l}\text { 6. Identification and dissection of the ethmoi- } \\
\text { dal bulla and the bulla complex. }\end{array}$} & \multirow{2}{*}{ No } & Checklist group & Median: 2,42 points & Range: 3.45 & \multirow{2}{*}{$p<0.001^{*}$} \\
\hline & & Control group & Median: 7,97 points & Range: 6.11 & \\
\hline \multirow{2}{*}{$\begin{array}{l}\text { 7. Identification and dissection of the fron- } \\
\text { toethmoidal cells. }\end{array}$} & \multirow{2}{*}{ No } & Checklist group & Median: 4,63 points & Range: 2.85 & \multirow{2}{*}{$\mathrm{p}<0.001^{*}$} \\
\hline & & Control group & Median: 8,98 points & Range: 2.88 & \\
\hline \multirow{2}{*}{$\begin{array}{l}\text { 8. Identification and dissection of the middle } \\
\text { turbinate and its attachments. Basal lamella of } \\
\text { the middle turbinate. }\end{array}$} & \multirow[b]{2}{*}{ No } & Checklist group & Median: 2,19 points & Range: 2.89 & \multirow{2}{*}{$\mathrm{p}<0.001^{*}$} \\
\hline & & Control group & Median: 7,66 points & Range: 6.09 & \\
\hline \multirow{2}{*}{$\begin{array}{l}\text { 9. Identification and total dissection of } \\
\text { ethmoids. }\end{array}$} & \multirow{2}{*}{ Yes } & Checklist group & Mean: 3,33 points & SD: 0.87 & \multirow{2}{*}{$\mathrm{p}<0.001^{*}$} \\
\hline & & Control group & Mean: 5,50 points & SD: 1.17 & \\
\hline \multirow{2}{*}{$\begin{array}{l}\text { 10. Identification and dissection of the sp- } \\
\text { henoid sinus. Sphenoidal approach. }\end{array}$} & \multirow{2}{*}{ Yes } & Checklist group & Mean: 1,53 points & SD: 0.84 & \multirow{2}{*}{$p=0.017$} \\
\hline & & Control group & Mean: 2,06 points & SD: 0.82 & \\
\hline \multirow{2}{*}{$\begin{array}{l}\text { 11. Identification of the frontal recess. Dissec- } \\
\text { tion of the frontal sinus. }\end{array}$} & \multirow{2}{*}{ No } & Checklist group & Median: 2,37 points & Range: 5.08 & \multirow{2}{*}{$p<0.001^{*}$} \\
\hline & & Control group & Median: 8,84 points & Range: 2.44 & \\
\hline
\end{tabular}

( Significance difference after statistical correction with the Bonferroni test)

\section{Results}

- Identification of essential anatomical references: Differences between groups to identify the essential anatomical references in the ESS were significant ( $p<0.045$ after Bonferroni correction) in 9 of the 11 essential anatomical references for the Checklist Group (ChG). No statistically significant difference was found for the "alignment of the nasal septum and its relationship with the middle meatus" and "identification and dissection of the sphenoid sinus" (Table 2, Figure 3).

- Complete and correct performed surgical procedures (checked at post-dissection (T): Six out of seven surgical procedures were performed equally well in both groups. Only " complete dissection to the different variants of frontoethmoidal cells according to the number and type that existed in the planning TC " was performed better in the ChG group (73.3\%) compared to CG group (10\%) ( $p<0.001$ after Bonferroni correction) (Table 3). - Complications and mistakes during ESS cadaveric dissection:There was a higher rate of mistakes committed by the CG compared to the ChG although the differences did not reach significance. Damage of the lamina papyracea or the orbit (CG: 26.7\%; ChG: 16.7\%), Damage of the lacrimal sac (CG: 6.7\%; ChG: $10 \%)$, Damage of the anterior ethmoidal artery (CG: 23.3\%; ChG: 10\%), Damage of the sphenopalatine artery (CG: 10\%; ChG: 6.7\%), Damage of the cribriform plate (CG: 26.7\%; ChG: $10 \%)$, Damage of the ethmoidal roof and the sphenoethmoidal recess (CG: 6.7\%; ChG: 0\%), Damage to the posterior wall of the sphenoid sinus and sella region (CG: 6.7\%; ChG: 0\%), Damage of the optico-carotid recess (CG: $3.3 \%$; ChG: $0 \%$ ). So although in this relatively small group the differences did not reach significance we advocate the use of the "ABCDEF Checklist" as a 
Table 3. Rate (\%) of success in achieving surgical procedures, and Chi-square test values..

\begin{tabular}{|c|c|c|c|}
\hline & Groups & $\begin{array}{l}\text { Rate }(\%) \text { of success in } \\
\text { achieving surgical proce- } \\
\text { dures }\end{array}$ & $P$ value (Chi-square test) \\
\hline \multirow[t]{2}{*}{ 1. Complete dissection of the agger nasi cell. } & Checklist group & $80 \%$ & \multirow{2}{*}{$p=0.028$} \\
\hline & Control group & $53.3 \%$ & \\
\hline \multirow[t]{2}{*}{ 2. Complete dissection of the uncinate process } & Checklist group & $80 \%$ & \multirow{2}{*}{$p=0.028$} \\
\hline & Control group & $53.3 \%$ & \\
\hline \multirow[t]{2}{*}{ 3. Frontal sinus dissection. } & Checklist group & $86.7 \%$ & \multirow{2}{*}{$p=0.020$} \\
\hline & Control group & $60 \%$ & \\
\hline \multirow[t]{2}{*}{ 4. Ethmoidal bulla dissection. } & Checklist group & $76.7 \%$ & \multirow{2}{*}{$p=0.017$} \\
\hline & Control group & $46.7 \%$ & \\
\hline \multirow{2}{*}{$\begin{array}{l}\text { 5. Complete dissection to the different variants of } \\
\text { frontoethmoidal cells according to the number and } \\
\text { type that existed in the planning TC. }\end{array}$} & Checklist group & $73.3 \%$ & \multirow{2}{*}{$\mathrm{p}<0,001^{*}$} \\
\hline & Control group & $10 \%$ & \\
\hline \multirow{2}{*}{$\begin{array}{l}\text { 6. Total ethmoidectomy. Anterior and posterior } \\
\text { ethmoidectomy to the ethmoidal roof. }\end{array}$} & Checklist group & $80 \%$ & \multirow{2}{*}{$p=0.542$} \\
\hline & Control group & $73.3 \%$ & \\
\hline \multirow[t]{2}{*}{ 7. Sphenoidotomy and sphenoidal dissection. } & Checklist group & $80 \%$ & \multirow{2}{*}{$p=0.152$} \\
\hline & Control group & $63.3 \%$ & \\
\hline
\end{tabular}

( ${ }^{*}$ Significance difference after statistical correction with the Bonferroni test).

tool for the preoperative planning of the ESS reduced the risk of mistakes or complications by the ENT surgeon.

\section{Discussion}

An improvement in the results of the aspects evaluated regarding the use of the "ABCDEF Checklist", and its 3D reproducibility for the pre-surgical planning of ESS make us consider its overall potential for this type of ENT surgery. The most relevant results may be summarized in that more than $80 \%$ of the anatomical references essential for ESS were better identified with the use of the Checklist; Most of the surgical procedures proposed during the cadaveric dissection were better executed, although not significantly better, by those surgeons who planned them with the Checklist, with special mention to the dissection of the different variants of frontoethmoidal cells (since it is a very variable sinonasal anatomical area that requires a particularly detailed study) that was performed significantly better by the checklist group.

The finding of failed surgeries and the persistence and recurrence of sinonasal diseases after ESS due to causes attributable to the surgeon ${ }^{(19,20)}$, repeatedly raises the need for support toward the radiological location of anatomical landmarks and their inter-relations oriented to the preoperative planning of surgery, despite knowledge of the advantages of navigation during image-guided surgery ${ }^{(21)}$. Checklists based on the standardization and systematization of the evaluation by radiological images in 2D have translated into a reduction of complications in between $8 \%$ and $19 \%$ of the neurosurgical approaches ${ }^{(22)}$, and an improvement of $36 \%$ in the rate of foreseeable failures associated with the ESS treatment of the sellar region and the skull base ${ }^{(23,24)}$. Even so, checklists have not prevented ESS from unsatisfactory outcomes, such surgeries constituting one of the main sources of legal demands in otolaryngology ${ }^{(25,26)}$. The aforementioned results were reproduced in our study, confirming that the use of the "ABCDEF Checklist" and its 3D reconstruction, reduced the mistakes rate, but did not eliminate it completely. For example, damage of the lamina papyracea of the orbit was reduced from $26.7 \%$ (CG) to $16.7 \%$ (ChG), or cribriform plate damage dropped from $26.7 \%$ (CG) to $10 \%$ (CG). Therefore, the use of this tool does not guarantee the range of error 0 , but it does help to minimize potential damage that might occur during ESS. The insistence of the World Health Organization (WHO) to use checklists aimed at minimizing avoidable errors and reducing surgical morbidity and mortality ${ }^{(27)}$, confirms the lack of widespread implementation of this tool in surgical settings. The repeated recommendations to use checklists in the training and planning of ESS reinforce the reality of their scarce use in routine clinical practice ${ }^{(28,29)}$. It is possible that one of the determining factors of this low use lies in the lack of consensus on terminology, which in many cases is ambiguous. In 2014, a European consensus on the terminology of the paranasal sinuses was published $^{(30)}$ in response to this need. Another new nomenclautres of fronto-ehtmoidal cells was proposed by Wormald ${ }^{(31)}$, oriented towards a novel classification on different surgical extensions of the same. This nomenclature is the basis of the "ABCDEF Checklist", presenting in an orderly fashion the fundamental 


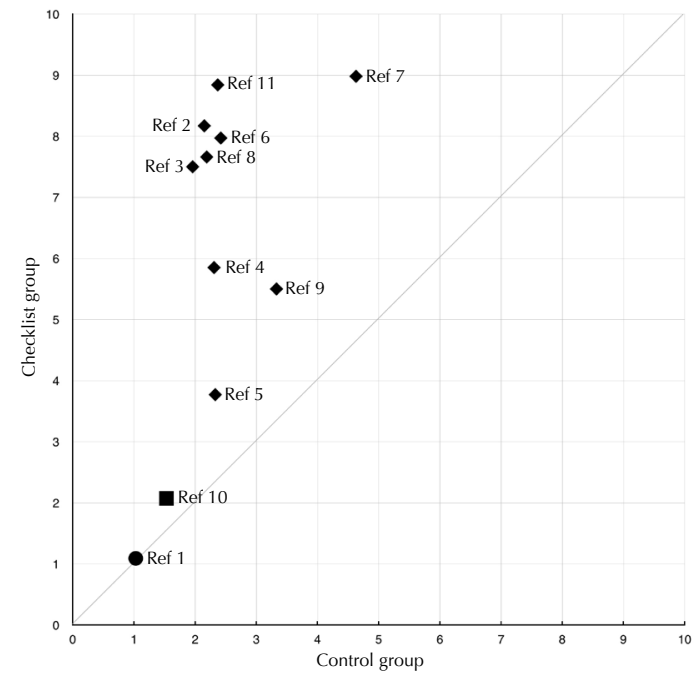

Figure 3. Statistical significance to anatomical references considered essential in the ESS.

- Alignment of the nasal septum and its relationship with the middle meatus (Ref 1).

- Identification and dissection of the agger nasi (Ref 2).

- Identification and dissection of the uncinate process. Relationship between the uncinate process and the maxillary sinus (Ref 3 ).

- Identification of the anterior ethmoidal artery (Ref 4).

- Identification of the sphenopalatine artery (Ref 5).

- Identification and dissection of the ethmoidal bulla and the bulla complex (Ref 6).

- Identification and dissection of the frontoethmoidal cells (Ref 7).

- Identification and dissection of the middle turbinate and its attachments. Basal lamella of the middle turbinate (Ref 8).

- Identification and total dissection of ethmoids (Ref 9).

- Identification and dissection of the sphenoid sinus. Sphenoidal approach (Ref 10).

- Identification of the frontal recess. Dissection of the frontal sinus (Ref 11).

(circle) No significant difference.

(diamond) Significant difference.

(square) No significant difference with Bonferroni test

terminology of the SSE.

Another possible determining factor is the difficulty offered by checklists based on 2D images of the craniofacial massif to solve the deficiencies that the human brain has when extrapolating $2 \mathrm{D}$ images in the volumetric structures found during ESS. Wormald proposed the artificial construction of 3D blocks ${ }^{(32,33)}$, to help solve this deficiency, and Chen et al. ${ }^{(34)}$ also noted an improvement of between $52 \%$ to $66 \%$ in outcomes of the frontal sinus approach, using 3D models. In addition, it is known that the use of 3D planning in ESS allows surgeons to execute approaches in a safer way, with greater confidence, and in a shorter surgical time than with the use of $2 \mathrm{D}$ images ${ }^{(35,36)}$.

This scenario reinforces the need both to have new tools that overcome the deficiencies and limitations observed, and to assume the WHO recommendations on checklists based on short, simple and specific foundations, that are useful in patient care practice ${ }^{(37)}$. The "ABCDEF Checklist" constitutes a methodological contribution that takes advantage of the use of radiological multiplane 3D images with the integration of the Horos ${ }^{\circledR}$ program to facilitate the cerebral recreation of volumes and volumetric relationships from $2 \mathrm{D}$ images, while minimizing the dependence on terminology ineffective surgical planning and also during ESS. The abbreviation (ABCDEF) used for the checklist follows an alphabetical sequence and represents a mnemonic support to remember all the essential anatomical references in ESS, unlike the "CLOSE" abbreviation proposed by O'Brien et al. ${ }^{(15)}$ which fundamentally refers to structures subject to potential damage during ESS. The simplicity of the concept is transferred to the individual identification of each of the essential anatomical references for obtaining an overview of each individual patient. The basic difference between the "CLOSE" methodology ${ }^{(15)}$ and the "ABCDEF" design lies in the fact that the first one analyzes in detail those structures that during the ESS are especially susceptible to being damaged, while the methodology that has been analyzed in the present manuscript, integrates the structures studied in the "CLOSE", interrelating them with all the essential anatomical references and risk areas to be addressed during the ESS. In addition, as mentioned above, the "ABCDEF Checklist" follows a 3D recreation methodology with Horos that increases the reproducibility of the preoperative findings in the paranasal sinuses and the base of the skull, once the ENT surgeon is in the surgery room, as the results of this study demonstrate (Tables 2 and 3). Perhaps the main drawback of the "ABCDEF Checklist" could be that it is lengthier than other checklists. However, the extension and format in which it is presented (Figure 1) is justified by a rationale based on the new recommendations and nomenclatures of the experts in the sinonasal area $a^{(1,30,31)}$.

The outcomes showed in this article agree with the results published by Syme-Grant et al. ${ }^{(8)}$ which accept that the learning methods evaluated so far have not been proven sufficient to achieve an adequate understanding of sinonasal anatomy to avoid revision surgeries due to surgeon mistakes. Furthermore, the methods of identification of these structures have not allowed to successfully perform ESS without complications or execution complications. The "ABCDEF Checklist" may become a useful tool for otolaryngologists, from those who are starting in this field, to more advanced specialists, and even for those with more experience facing unexpected complications or failed surgeries.

\section{Conclusion}

The "ABCDEF checklist" based on 3D radiological images inte- 
grates the most relevant anatomical sinonasal structures in an orderly fashion. Its use prior to ESS facilitates the identification of essential landmarks for systematized and preoperative planning of surgical procedures.

The "ABCDEF checklist" is a suitable tool to be included in the surgical management protocol of the pathologies in which ESS is indicated, as well as for training and learning.

\section{Acknowledgement}

We are grateful to all participants who voluntarily enrolled in this project. We thank Rosa Bautista, for the collaboration in the translation of the manuscript and editorial assistance. The authors are also grateful for the collaboration of the Ministry of
Health of the Junta de Andalucía and Project PI-0212-2017.

\section{Authorship contribution}

Conception: MSJM, GGJ, SGS. Design: MSJM, GGJ, RML, SGS.

Supervision: MSJM, SGS. Resource: MSJM, SGS, AFJ. Materials: MSJM, GGJ, MLR, AFJ, DDE, SGS. Data collection and/or processing: MSJM, EDD, SGS. Analysis and/or interpretation: MSJM, EDD, SGS. Literatura search: MSJM, MLR, GGJ, SGS. Writing: MSJM, MLR, GGJ, AFJ, SGS. Critical reviews: MSJM, MLR, GGJ, AFJ, DDE.

\section{Conflict of interest}

No conflicts of interest to disclose.
1. Lund VJ, Stammberger $H$, Nicolai $P$, et al. European Rhinologic Society Advisory Board on Endoscopic techniques in the management of nose, paranasal sinus and skull base tumors. European position paper on endoscopic management of tumors of the nose, paranasal sinuses and skull base. Rhinol Suppl. 2010;(22):1-143.

2. Rudmik L, Soler ZM, Hopkins C, Schlosser RJ, Peters A, White AA, et al. Defining appropriateness criteria for endoscopic sinus surgery during management of uncomplicated adult chronic rhinosinusitis: a RAND/ UCLA appropriateness study. Rhinology. 2016;54(2):117-28.

3. Rudmik L, Soler ZM, Hopkins C. Using postoperative SNOT-22 to help predict the probability of revision sinus surgery. Rhinology. 2016;54(2):111-6.

4. Shah RK, Nussenbaum B, Kienstra M, Glenn $M$, Brereton J, Patel MM, et al. Wrongsite sinus surgery in otolaryngology. Otolaryngology-Head and Neck Surgery. 2010;143:37-41.

5. Stankiewicz J, Lal D, Welch K, et al. Complications in endoscopic sinus surgery: a 25 year experience. Laryngoscope. 2011;121:2684-701.

6. Krings JG, Kallogjeri D, Wineland A, Nepple KG, Piccirillo JF, Getz AE. Complications of primary and revision functional endoscopic sinus surgery for chronic rhinosinusitis. Laryngoscope 2014;124(4):838-845.

7. Thone N, Winter M, García-Matte RJ, González C. Simulación en otorrinolaringología: una herramienta de enseñanza y entrenamiento. Acta Otorrinolaringol Esp. 2017;68:115-20

8. Syme-Grant J, White PS, McAleer P. Measuring competence in endoscopic sinus surgery. Surgeon. 2008;6:37-44.

9. Rudmik L, Xu Y, Alt JA, Deconde A, Smith TL, Schlosser RJ, Quan H, Soler ZM. Evaluating surgeon-specific performance for endoscopic sinus surgery. JAMA Otolaryngol Head Neck Surg. 2017;1;143(9):891-898.

10. Raju P, Anand KD, Osamu S, et al. Anatomical variants and pearls-functional endoscopic sinus surgery. Otolaryngol Clin N Am 2004;37:221-42.

11. Joe JK, Ho SY, Yanagisawa E. Documentation of variations in sinonasal anatomy by intraoperative nasal endoscopy. Laryngoscope. 2000;110:229-35.

12. Deutschmann MW, Yeung J, Bosch M, et al. Radiologic reporting for paranasal sinus computed tomography: a multi-institutional review of content and consistency. Laryngoscope 2013;123(5):1100-1105.

13. Soler ZM, Smith TL. Endoscopic sinus surgery checklist. Laryngoscope. 2012;122:137139.

14. Error M, Ashby S, Orlandi RR, Alt JA. Singleblinded prospective implementation of a preoperative imaging checklist for endoscopic sinus surgery. Otolaryngol Head Neck Surg. 2018;158(1):177-180

15. O'Brien WT, Hamelin S, Weitzel EK. The preoperative sinus CT: avoiding a "CLOSE" call with surgical complications. Radiology 2016;28(1):10-21.

16. Soyka MB, Treumann T, Schlegel CT. The Agger Nasi cell and uncinate process, the keys to proper access to the nasolacrimal drainage system. Rhinology. 2010;48(3):3647

17. Georgalas C, Fokkens W. Basic surgical techniques in endoscopic sinus surgery. In Rhinology and skull base surgery. From the lab to the operating room: An evidence-based approach. Georgalas C, Fokkens W, eds. Basic Surgical Techniques in Endoscopic Sinus Surgery. New York: Thieme, 2013; 311-325.

18. Casiano R. Endoscopic Sinonasal Dissection Guide. New York: Thieme, 2011.

19. Khalil HS, Eweiss AZ, Clifton N. Radiological findings in patients undergoing revision endoscopic sinus surgery: a retrospective. BMC Ear, Nose and Throat Disorders 2011;11:4.

20. Huang BY, Lloyd KM, DelGaudio JM, Jablonowski E, Hudgins PA. Failed endoscopic sinus surgery: Spectrum of CT findings in the Frontal Recess. RadioGraphics 2009;29:177-119.
21. Bewick J, Egro FM, Masterson L, Javer AR, Philpott CM. Anatomic findings in revision endoscopic sinus surgery: Case series and review of contributory factors. Allergy Rhinol. 2016;7(3):151-157.

22. Lepänluoma M, Takala R, Kotkansalo A, Rahi M, Ikonen TS. Surgical safety checklist is associated with improved operating room safety culture, reduced wound complications, and unplanned readmissions in a pilot study in neurosurgery. Scand I Surg. 2014;103:66-72.

23. Christian E, Harris B, Wrobel B, Zada G. Endoscopic endonasal transphenoidal surgery: implementation of an operative and perioperative checklist. Neurosurg Focus. 2014;37(4):E1.

24. Laws ER, Wong JM, Smith TR, et al. A checklist for endonasal transphenoidal anterior skull base surgery. J Neurosurg. 2016;124:1634-1639.

25. Stankiewicz JA, Hotaling J. Medicolegal issues in endoscopic sinus surgery and complications. Otolaryngol Clin N Am. 2015;48:827-837.

26. Shah RK, Nussenbaum B, Kienstra M, Glenn $M$, Brereton J, Patel MM, et al. Wrongsite sinus surgery in otolaryngology. Otolaryngology-Head and Neck Surgery. 2010;143:37-41.

27. Haynes AB, Weiser TG, Berry WR, et al. A surgical safety checklist to reduce morbidity and mortality in a global population. N Engl J Med. 2009;360:491-499.

28. Steehler MK, Chu EE, Na H, et al. Teaching and assessing endoscopic sinus surgery skills on a validated low-cost task trainer. Laryngoscope. 2013;123:841-844.

29. Yao CM, Fernandes VT, Palmer JN, Lee JM Educational value of a preoperative CT sinus checklist: a resident's perspective. J Surg Educ. 2013;70(5):585-587.

30. Lund VJ, Stammberger H, Fokkens WJ, et al. European Position Paper on the Anatomical Terminology of the internal Nose and Paranasal Sinuses. Rhinol Suppl. 2014 Mar;(24): 1-34.

31. Wormald PJ, Hosemann W, Callejas C, Weber 
RK, Kennedy DW, et al. The Internationa Frontal Sinus Anatomy Classification (IFAC) and Classification of the Extent of Endoscopic Frontal Sinus Surgery (EFSS). Int Forum Allergy Rhinol. 2016;6(7):677-96.

32. Wormald PJ. Three-dimensional building block approach to understanding the anatomy of the frontal recess and frontal sinus. Oper Tech Otolaryngol Head Neck Surg. 2006;17:2-5.

33. Wormald PJ. Endoscopic sinus surgery Anatomy, three-dimensional reconstruction and surgical technique. New York: Thieme, 2013.

34. Chen PG, McMains KCh, Tewfik MA, et al. Teaching frontal sinus anatomy using the frontal sinus masterclass 3D concep- tualization model. Laryngoscope. 2017. doi:10.1002/lary.26939.

35. Bisdas S, Verink M, Burmeister HP, Stieve $M$, Becker $\mathrm{H}$. Three-dimensional visualization of the nasal cavity and paranasal sinuses. J Comput Assist Tomogr. 2004;2(5)

36. Sánchez-Gómez S, Herrero-Salado T, MazaSolano JM, et al. Mejora de la planificación de las cirugías endoscópicas nasosinusales a partir de imágenes en 3 dimensiones con Osirix ${ }^{\circledR}$ y estereolitografía. Acta Otorrinolaringol Esp. 2015;66:317-325.

37. Weiser TG, Haynes AB, Lashoher A, et al Perspectives in quality: designing the $\mathrm{WHO}$ Surgical Safety Checklist. Int J Qual Health Care. 2010;22:365-370.
Juan Manuel Maza-Solano, MD, PhD

Rhinology and Anterior Skull Base

Department Section

University Hospital Virgen Macarena,

Av. Doctor Fedriani 3

\section{E-41071, Sevilla}

Spain

Tel.: +34 605133748,

E-mail: juan.maza.solano@gmail.com 